\title{
Reduction of Circulating Cholesterol and Apolipoprotein Levels during Sepsis
}

\author{
Peter Fraunberger ${ }^{1}$, Steffen Schaefer ${ }^{2}$, Karl Werdan², \\ Autar K. Walli ${ }^{1}$ and Dietrich Seidel ${ }^{1}$ \\ ${ }^{1}$ Institute of Clinical Chemistry, Klinikum Grosshadern, Uni- \\ versity of Munich, Munich, Germany \\ ${ }^{2}$ Chair of Cardiac Intensive Care Medicine, Klinikum Kroell- \\ witz, University of Halle- Wittenberg, Halle, Germany
}

Sepsis with multiple organ failure is frequently associated with a substantial decrease of cholesterol levels. This decrease of cholesterol is strongly associated with mortality suggesting a direct relation between inflammatory conditions and altered cholesterol homeostasis. The host response during sepsis is mediated by cytokines and growth factors, which are capable of influencing lipid metabolism. Conversely lipoproteins are also capable of modulating cytokine production during the inflammatory response. Therefore the decrease in circulating cholesterol levels seems to play a crucial role in the pathophysiology of sepsis. In this review the interaction between cytokines and lipid metabolism and its clinical consequences will be discussed.

Key words: Hypocholesterolemia; Mortality; Lipoproteins; Sepsis; Cytokines; Inflammation; TNF- $\alpha$; TNF receptors; IL-6.

\section{Introduction}

Hypocholesterolemia during inflammatory diseases was already observed at the beginning of this century. In 1911, Chauffard et al. (1) reported diminished cholesterol levels during the febrile phase of tuberculosis, especially in patients with "very bad general condition". In 1920, Kipp (2) reported a decrease in cholesterol levels during various other pulmonary infections. He noted a relationship between the degree of hypocholesterolemia and the severity of infection. During the next decades changes in lipoprotein profile during inflammatory diseases were reported. Burn injuries led to a profound decrease of cholesterol within a few days, with the lowest levels between the sixth and tenth day and a subsequent increase during the next 12 weeks (3). Both low density lipoproteins (LDL) and high density lipoproteins (HDL), which carry over 80 percent of total cholesterol in humans, decreased. In contrast, triglyceride-rich very low density lipoproteins (VLDL) increased in the acute phase. Similarly, in patients with sepsis, a decrease in serum levels of total cholesterol, HDL-cholesterol and apolipoprotein (apo)-
A1 and apo-B and an increase of serum triglycerides have been reported (4). These changes in lipoprotein profile were independent of the underlying disease or infectious agents causing sepsis. Sammalkorpi etal. (5) confirmed these results in patients with bacterial and viral infections. In addition, some recent studies reported very low levels of total cholesterol levels in critically ill patients (6), trauma patients (7) and postoperatively in patients after major surgery (8). The degree of hypocholesterolemia in all these studies seems to depend on the severity of the disease, with the lowest levels in critically ill patients with sepsis.

The fact that all inflammatory diseases with and without infection lead to a decrease in serum cholesterol levels suggests a common mechanism. Several experimental and clinical studies indicate that the immune response of the organism which is mediated by the release of cytokines and growth factors, is responsible for the cholesterol decrease. However, the effects of cytokines on lipoprotein metabolism are complex and the mechanisms leading to low cholesterol levels have not been studied in detail. Some preliminary studies suggest a protective role of lipoproteins during inflammation; therefore changes of lipoprotein profile may play a crucial role in inflammatory conditions and be indicative of prognostic outcome in these patients.

\section{Cholesterol and Mortality}

In a large cohort of hospitalized patients with cholesterol levels below $2.6 \mathrm{mmol} / \mathrm{l}(100 \mathrm{mg} / \mathrm{dl})$ a ten fold higher mortality was reported, which inversely correlated with cholesterol levels (9). In a recent study on patients with intra-abdominal infections after emergency operations, hypocholesterolemia, in addition to acute physiology and chronic health (APACHE) II score, hypoalbuminemia and preoperative organ impairment, were shown to be independent predictors of mortality (10). We also observed in 33 critically ill patients (APACHE score $32 \pm 6$; range $20-44$ ) that low cholesterol levels correlated with mortality (Figure 1). To further evaluate the diagnostic value of serum cholesterol we followed circulating cholesterol levels of seven patients with septic shock during their stay in the hospital. Patients with persistent cholesterol levels under $2.6 \mathrm{mmol} / \mathrm{l}(100 \mathrm{mg} / \mathrm{dl})$ had highest mortality in contrast to patients whose cholesterol levels increased (Figure 2). These observations stress the importance of fluctuations of serum cholesterol levels during inflammatory conditions and mortality. 


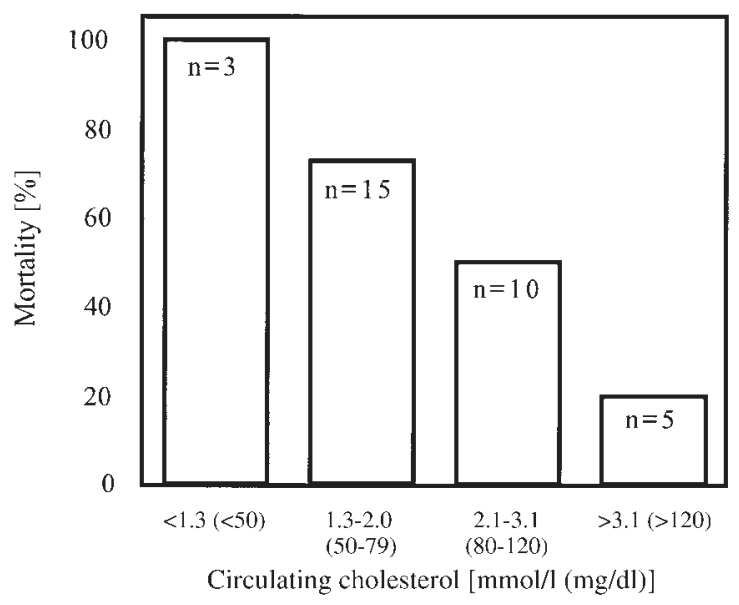

Fig. 1 Serum cholesterol levels in relation to mortality in critically ill patients. A very high mortality was found in patients with cholesterol levels lower than $1.3 \mathrm{mmol} / \mathrm{l}(50 \mathrm{mg} / \mathrm{dl})$ whereas increasing cholesterol levels were associated with lower mortality.

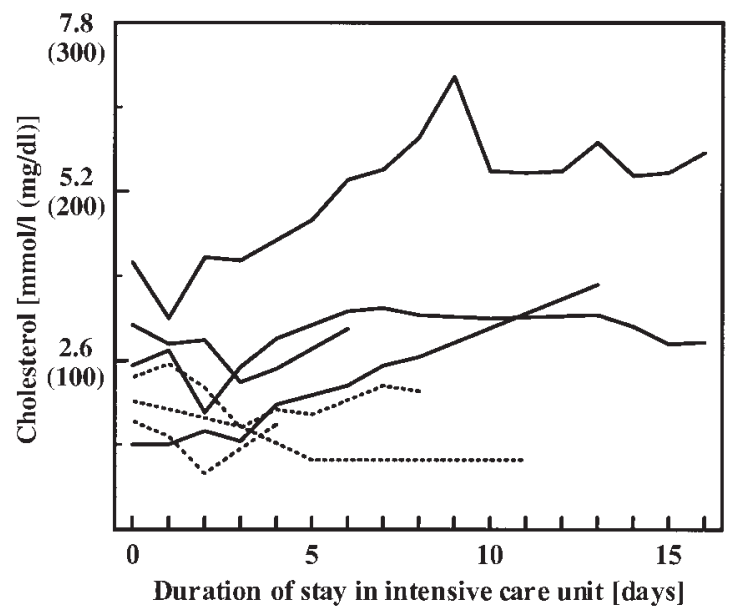

Fig. 2 Cholesterol levels in 7 patients with septic shock during their stay in the intensive care unit. Dotted lines represent the three non-survivors (adapted with permission from Fraunberger et al., see reference 12).

\section{Cytokine Release as a Possible Mechanism for Hypo- cholesterolemia during Inflammation}

The response of the organism to inflammation and infection is mediated by the release of cytokines. In particular, pro-inflammatory cytokines, such as tumor necrosis factor- $\alpha$ (TNF- $\alpha$ ), interleukin (IL)- 1 and IL-6, and also growth factors such as platelet-derived growth factor (PDGF), transforming growth factor (TGF) and colony stimulating factors modulate lipid metabolism (11). Several clinical and experimental studies suggest that high circulating levels of cytokines may be related to hypocholesterolemia of inflammation.

In inflammatory conditions, circulating cholesterol levels decrease, whereas cytokine levels are elevated. Thus a significant inverse correlation between serum levels of TNF- $\alpha$ and cholesterol was noted (12). However, because of the short biological half life of TNF- $\alpha$, this correlation may not always be evident. Nevertheless, concomitant with the release of TNF- $\alpha$, soluble
TNF- $\alpha$ receptors-p55 and -p75 are also shed into the circulation. These receptors, which have a longer biological half life than TNF- $\alpha$, remain elevated for several days and may therefore correlate better than TNF- $\alpha$ with cholesterol. Besides TNF- $\alpha$, other cytokines may also play a role in decreasing cholesterol. For example, after major surgery, an increased serum level of IL-6 was accompanied by a decrease in cholesterol levels, and an inverse correlation between cholesterol and IL6 serum levels was noted (8). Also, infusion of cytokines such as TNF- $\alpha$ and IL- 6 as well as IL-2 or granulocyte/macrophage colony stimulating factor (GMCSF), during cancer therapy leads to a large decrease in serum cholesterol (13-16). Therefore, other cytokines may also contribute to hypocholesterolemia, however little information is available about correlation between serum levels of these cytokines and cholesterol.

\section{In vitro observations}

Whether the decrease of cholesterol during inflammation is due to accelerated clearance of lipoproteins or to diminished synthesis and secretion of lipoprotein precursors by the liver, the major organ for synthesis and catabolism of lipoproteins, is still unclear. In vitro studies lend support to both hypotheses. In HepG2 cells, which serve as a model for liver cells, TNF- $\alpha$, IL-1 and IL- 6 decrease the accumulation of apo-Al and apo-B and lecithin : cholesterol acyltransferase in the medium and all three cytokines also decrease expression of m-RNA for apo-A1 but not for apo-B (17). In contrast, in a recent study, IL-1 and IL- 6 were shown to markedly increase mRNA for apo-B but enhance intracellular degradation of apo-B (18). In addition, a recent study showed that IL-1 $\beta$ and TNF- $\alpha$ decrease the apo-A 1 and apo-E concentration in the culture medium of HepG2 cells (19). However, the rapid decrease of cholesterol carrying lipoproteins, which usually have a relatively

Tab. 1 Cytokines with stimulatory effect on LDL receptor activity in various human cell systems.

\begin{tabular}{lll}
\hline Cell system & Cytokines & Source \\
\hline Skin fibroblasts & PDGF, EGF & 20 \\
& TNF- $\alpha$ & 12,21 \\
Monocyte-derived & MCSF, IL-1, GMCSF & 22 \\
macrophages & PDGF & 23 \\
Endothelial cells & TNF- $\alpha$ & 12,21 \\
HepG2 cells & OSM, IL-6, IL-1, TGF- $\beta$ & 24 \\
& TNF- $\alpha$, IL-1 & 12,25 \\
& TGF- $\beta$, IL-1 & 26 \\
& EGF & 27 \\
& HGF & 28 \\
& LIF & 29 \\
& TNF- $\alpha$ & 30
\end{tabular}

Abbreviations: PDGF-platelet derived growth factor; EGF-epidermal growth factor; TNF- $\alpha$-tumor necrosis factor- $\alpha$; MCSFmacrophage-derived growth factor; GMCSF-granulocyte/macrophage colony stimulating factor; OSM-Oncostatin $M$; HGF-hepatocyte growth factor; LIF-leukemia inhibitory factor. 
slow fractional catabolic rate and a greater pool size argues against this hypothesis. Other mechanisms leading to an increased utilization of lipoproteins may play an important role in lowering serum cholesterol levels in sepsis. Studies on cultured cells indeed show that various cytokines and growth factors are capable of enhancing lipoprotein uptake and catabolism (Table $1)$.

It is therefore feasible that release of cytokines during inflammation may lead to an increased cellular LDL receptor activity, resulting in hypocholesterolemia of inflammatory conditions. In view of the cytokine profile which is observed in sera of septic patients, pro-inflammatory cytokines such as TNF- $\alpha$, IL- 1 or IL- 6 are the most likely candidates to cause diminution in circulating cholesterol levels. However cytokine release is usually accompanied by the release of physiological inhibitors with possible protective effects. For example, the biological activity of TNF- $\alpha$ is regulated by two soluble TNF- $\alpha$ receptors, TNFR-p55 and TNFR-p75 (30). The extra-cellular domain of these receptors is cleaved and shed into the circulation. The concentration of these receptors is increased by several orders of magnitude and should be capable of neutralizing the biological activity of active TNF- $\alpha$ (31). In vitro studies with cultured fibroblasts demonstrate that a very high molar excess of TNF- $\alpha$ receptors over TNF- $\alpha$ is required to inhibit TNF- $\alpha$-induced increase of LDL receptor activity (12). Thus, over 1000 -fold excess of TNF- $\alpha$ receptors is required to diminish the TNF- $\alpha$-induced increase in LDL utilization by about 60 to $70 \%$ (Figure 3). However in critically ill patients, measurement of serum levels of TNF- $\alpha(56.1 \pm 20.5 \mathrm{pg} / \mathrm{ml})$ and TNF- $\alpha$ receptors (p55: $14.7 \pm 4.6$ and $p 75: 14.1 \pm 3.1 \mathrm{ng} / \mathrm{ml}$ ) showed only a 250 fold molar excess of TNF- $\alpha$ receptors over TNF- $\alpha$. Extrapolating from in vitro data, only about $20 \%$ decrease in TNF- $\alpha$-induced stimulation of LDL receptor activity could be expected and this is therefore insufficient to counteract hypocholesterolemic effects of TNF- $\alpha$.
In summary data from in vitro studies suggest that cytokines are capable of decreasing hepatic lipoprotein production and increasing LDL receptor activity, and both of these effects can lead to low serum cholesterol levels during inflammatory diseases. Further in vivo studies should clarify to what extent these two mechanisms contribute to hypocholesterolemia during inflammation.

\section{Animal studies}

The use of animal models for studying lipid metabolism is limited by the fact that the effect of endotoxin and cytokines on cholesterol metabolism is different in primates and rodents. In rats and mice, infusion of lipopolysaccaride (LPS) or TNF- $\alpha$, which is the central mediator of the endotoxin effect, stimulates hepatic lipogenesis with subsequent increase of cholesterol and triglycerides. This increase is possibly due to an increased hepatic production of VLDL $(32,33)$. However in rats and mice circulating $\mathrm{HDL}$ is the main plasma lipoprotein, instead of LDL, which is the major lipoprotein in humans. Since metabolism of HDL is not affected by LPS, the data from these animal models need caution and cannot be directly compared to data in humans. In contrast, in primates, which have a similar qualitative lipoprotein profile to humans, infusion of LPS or TNF- $\alpha$ induces a profound fall of plasma cholesterol $(34,35)$. Although the data obtained from clinical and experimental studies in primates support the hypothesis that cytokine release may be responsible for cholesterol decrease, no data are yet available showing that neutralization of cytokines prevents hypocholesterolemia during inflammation. Turnover studies with radioactive labeled lipoproteins in the presence and absence of anti-cytokine antibodies are required to elucidate the mechanism for the LPS-induced decrease in circulating cholesterol levels.

Pro-inflammatory cytokines have also been reported to alter the metabolism of triglyceride-rich lipoproteins.

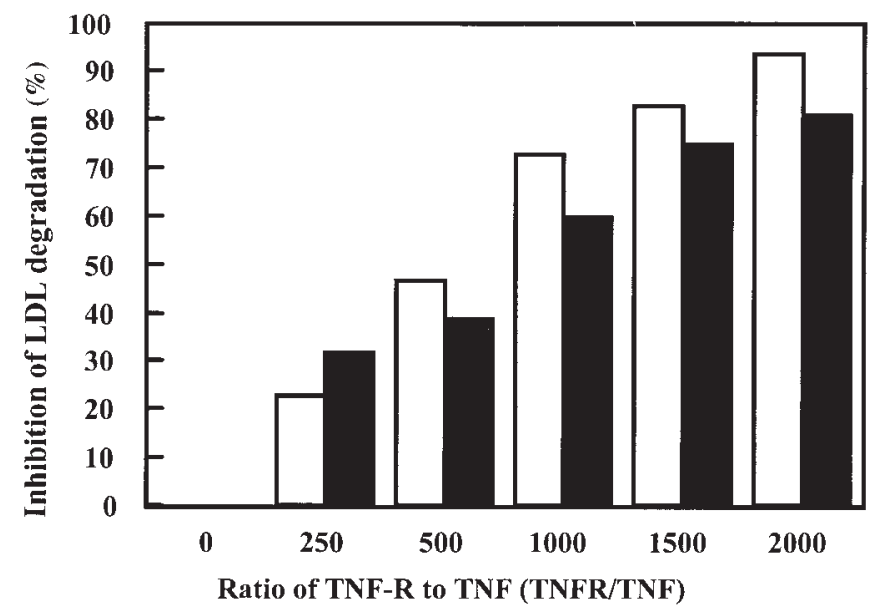

Fig. 3 Dose-dependent inhibition of TNF- $\alpha$ induced increase of specific degradation of ${ }^{125}$-LDL in cultured human fibroblasts by soluble TNF- $\alpha$ receptors (TNF-R). Cells were incubated with a concentration of $0.1 \mathrm{ng} / \mathrm{ml}$ TNF and increasing concentrations of TNF-R p55 or p75 for 24 hours. Thereafter monolayers were washed with PBS and incubated in albumin medium with ${ }^{125} \mathrm{LDL}\left(10 \mu \mathrm{g}\right.$ protein/ml) for 5 hours at $37^{\circ} \mathrm{C}$ in the presence or absence of $250 \mu \mathrm{g}$ unlabeled LDL, to obtain specific degradation. The assays were performed in triplicate. The degradation of ${ }^{125}$-LDL in the absence and presence of TNF- $\alpha$ was 1447 to $2489 \mathrm{ng} / \mathrm{mg}$ cell protein, respectively. $\square$ p55, $\square$ p75 
During inflammatory diseases in humans, as well as in experimental animals challenged with endotoxin, an increase of triglyceride-rich lipoproteins was observed $(4,33)$. This may either be due to an increased production of VLDL or to a diminished conversion of VLDL to LDL by inhibition of lipoprotein lipase (LPL) activity (33, 36,37 ). Endotoxin and TNF- $\alpha$ stimulate hepatic and adipose tissue lipolysis as well as hepatic fatty acid synthesis, which serve as substrates for hepatic VLDL synthesis $(36,38)$. The hypertriglyceridemia observed in inflammatory conditions may thus result from increased VLDL synthesis and secretion, or be due to decreased clearance of triglyceride-rich lipoproteins. Various studies report that endotoxin and TNF- $\alpha$ decrease the adipose tissue and post-heparin plasma LPL activity $(36,38,39)$. Therefore it is feasible that a combination of overproduction and decreased clearance of triglyceride-rich lipoproteins brings about hypertriglyceridemia of inflammation and infection. Even though antibodies to TNF- $\alpha$ reverse hypertriglyceridemic effects of TNF- $\alpha$, they fail to correct endotoxin or E.coli-induced hypertriglyceridemia $(38,40)$. This suggests that cytokines other than TNF- $\alpha$ may modulate the LPL activity. It has been reported that in addition to TNF- $\alpha$, IL-1, IL-6, IFN- $\alpha$ and IFN- $\gamma$ also suppress the activity of LPL (41-44). It should be noted that cytokines require several hours to decrease LPL activity in vivo (40). The acute hypertriglyceridemia resulting from TNF- $\alpha$ administration is manifest before the decrease in LPL activity, suggesting that alterations in the activity of this enzyme are not solely responsible for the observed effects. Decreased LPL activity following endotoxin or cytokine administration may sustain hypertriglyceridemia in inflammation.

\section{Possible Protective Role of Lipoproteins}

Triglyceride-rich lipoproteins such as chylomicrons, VLDL and their remnant particles may play a protective role during endotoxinemia $(45,46)$. One explanation for these effects could be increased supply of energy stores to peripheral cell systems by these lipoproteins. It is also possible that chylomicrons and VLDL as well as recombinant apo-E are capable of redirecting LPS from macrophages to hepatocytes, thus diminishing the response of macrophages to endotoxin (47-49). This may not only lead to an increased endotoxin excretion into bile but also reduce endotoxin-induced cytokine production and mortality. However this protective effect is not only restricted to triglyceride-rich lipoproteins. A similar observation was made with HDL in rabbits with gram-negative bacteremia and also in endotoxemic mice treated with $\operatorname{LDL}$ and $\operatorname{HDL}(45,50)$. In these models the protective effect of lipoproteins was associated with a significantly diminished TNF- $\alpha$ release and mortality after LPS administration. The protective role of lipoproteins is further supported by studies in hypolipidemic rat models, which showed higher sensitivity to LPS challenge (50). Data from in vitro studies show that lipoproteins bind and neutralize en- dotoxin. Incubation of monocyte/macrophages with LPS in the presence of LDL, oxidized LDL, HDL, apo-A1 as well as lipoprotein(a) (Lp(a)) was associated with significant reduction in cytokine synthesis and release by macrophages (52-54). Wurfel et al. (55) suggested an interaction between LPS-binding protein (LBP), soluble CD14 (sCD14) (LPS-receptor) and reconstituted HDL as one mechanism for this protective effect. It was suggested that CD14 facilitates the transfer of LPS from LBP to HDL or other lipoproteins. The anti-inflammatory effect of reconstituted HDL (rHDL) during endotoxinemia was confirmed in humans to whom low doses of LPS were administered with and without HDL. rHDL was able to reduce pro-inflammatory cytokine release and sCD14 expression in monocytes (56). Although the exact mechanism for the LPS neutralization is not yet exactly clarified, all these studies suggest a protective effect of lipoproteins during sepsis. Independent of a LPS neutralizing potential, the increase of free fatty acids during inflammation may also have a protective function because of their role in activation of peroxisome proliferator-activated receptors (PPARs) (57). It has been reported that these receptors antagonize the effects of transcription factors such as AP-1, STAT-1 and NF- $\mathrm{KB}$ and thereby diminish the synthesis and release of inflammatory cytokines $(58,59)$. Whether these in vitro observations also reflect the situation in inflammatory disease remains to be established.

\section{Conclusions}

Decreased cholesterol levels, which frequently occur during inflammation, correlate with severity of disease and outcome. Release of cytokines and growth factors during inflammation may be responsible for the changes in lipoprotein profile. Hypocholesterolemia, which is either due to increased consumption or to diminished production of lipoproteins, represents the metabolic response of the organism to the inflammatory event.

In rodents, the increase in triglyceride-rich lipoproteins together with the unchanged HDL-cholesterol levels during endotoxinemia, were capable of neutralizing endotoxin effects, thus preventing the organism from excessive cytokine levels, which are deleterious. In sepsis or septic shock in humans, this protective mechanism may fail due to low circulating lipoprotein levels. This could explain the inverse correlation of cholesterol and mortality in patients with sepsis. Whether infusion of certain isolated lipoproteins or recombinant lipoproteins may be beneficial as an adjuvant therapy in inflammatory disease deserves consideration.

\section{References}

1. Chauffard A, Richet C, Grigaut A. La cholesterinemia au cours de la tuberculose pulmonaire. Compt Rend Soc Biol 1911; Ixx: 276-7.

2. Kipp HA. Variation in the cholesterol content of the serum in pneumonia.J Biol Chem 1920; 44:215-37. 
3. Coombes EJ, Shakespeare PG, Batstone GF. Lipoprotein changes after burn injury in man. J Trauma 1980; 20:971-5.

4. Alvarez C, Ramos A. Lipids, lipoproteins, and apoproteins in serum during infection. Clin Chem 1986; 32:142-5.

5. Sammalkorpi K, Valtonen V, Kertulla Y, Nikkilä E, Taskinen M-R. Changes in serum lipoprotein pattern induced by acute infections. Metabolism 1988; 37: 859-65.

6. Gordon BR, Parker TS, Levine DM, Saal SD, Wang J C, Sloan BJ , et al. Low lipid concentration in critical illness: implications for preventing and treating endotoxemia. Crit Care Med 1996; 24:584-9.

7. Elliot DC, Wiles CE. Low lipid concentration in critical illness: hypocholesterolemia among trauma patients [letter]. Crit Care Med 1997; 25:1437-9.

8. Akgün S, Ertel NH, Mosenthal A, Oser W. Postsurgical reduction of serum lipoproteins: interleukin- 6 and the acute phase response. J Lab Clin Med 1998; 131:103-8.

9. Windler E, Ewers-Grabow U, Thiery J , Walli A, Seidel D, Greten $\mathrm{H}$. The prognostic value of hypocholesterolemia in hospitalized patients. Clin Invest 1994; 72:939-43.

10. Pacelli F, Doglietto GB, Alfieri S, Piccioni E, Sgadari A, Gui $D$, et al. Prognosis in intra-abdominal infections. Multivariate analysis on 604 patients. Arch Surg 1996; 131: 641-5.

11. Hardaróttir I, Grünfeld C, Feingold KR. Effects of endotoxin and cytokines on lipid metabolism. Curr Opinion Lipidology 1994; 5:207-15.

12. Fraunberger P, Pilz G, Cremer P, Werdan K, Walli AK. Association of serum TNF levels with decrease of cholesterol during septic shock. Shock 1998; 10:1-5.

13. Spriggs DR, Sherman ML, Michie $H$, Arthur KA, Imamura $\mathrm{K}$, Wilmore $\mathrm{D}$, et al. Recombinant human tumor necrosis factor administered as a 24-hour intravenous infusion. A phase I and pharmacological study. J Natl Cancer Inst 1988; 80:1039-44.

14. Van Gameren MM, Willemse PHB, Mulder NH, Limburg PC, Groen HJ M, Vellenga E, et al. Effects of recombinant interleukin- 6 in cancer patients: a phase I-II study. Blood 1994; 5:1434-41.

15. Wilson DE, Birchfield GR, Hejazi J S, Ward J H, Samlowski WE. Hypocholesterolemia in patients treated with recombinant interleukin-2: appearence of remnant-like lipoproteins. J Clin Oncol 1989; 7:1573-7.

16. Nimer SD, Champlin RE, Golde DW. Serum cholesterollowering activity of granulocyte-macrophage colony-stimulating factor. J Am Med Assoc 1988; 260:3297-300.

17. Ettinger $W H$, Varma VK, Sorci-Thomas M, Parks J S, Sigmon RC, Smith TK, et al. Cytokines decrease apolipoprotein accumulation in medium from HepG2 cells. Arterioscler Throm 1994; 14:8-13.

18. Yokoyama K, Ishibashi T, Yi-qiang L, Nagayoshi A, Teramoto T, Maruyama Y. Interleukin-1 $\beta$ and interleukin- 6 increase levels of apolipoprotein B mRNA and decrease accumulation of its protein in culture medium of HepG2 cells. J Lip Res 1998; 39:103-13.

19. Song H, Saito K, Fujigaki S, Noma A, Ishiguro H, Nagatsu $\mathrm{T}$, et al. IL-1 beta and TNF-alpha suppress apolipoprotein (apo) E secretion and apo A-I expression in HepG2 cells. Cytokine 1998; 10:275-80.

20. Chait A, Russ R, Albers ل, Bierman EL. Platelet-derived growth factor stimulates activity of low density lipoprotein receptors. Proc Natl Acad Sci 1980; 77: 4084-8.

21. Harada K, Shimano H, Kawakami M, Ishibashi S, Gotoda T, Mori $\mathrm{N}$, et al. Effect of tumor necrosis factor/cachectin on the activity of the low density lipoprotein receptor on human skin fibroblast. Biochem Biophys Res Comm 1990 172:1022-7.

22. Ishibashi S, Inaba T, Shimano H, Harada K, Inoue I, Mo- kuno $\mathrm{H}$, et al. Monocyte colony-stimulating factor enhances uptake and degradation of acetylated low density lipoproteins and cholesterol esterification in human monocyte-derived macrophages. J Biol Chem 1990; 265:14109-17.

23. Aviram M. Platelet secretory products enhance LDL receptor activity and inhibit scavenger receptor activity in human monocyte derived macrophages. Metabolism 1989; 38:425-30.

24. Grove RI, Mazzucco C, Allegretto N, Kiener PA, Spitalny G, Radka SF, et al. Macrophage-derived factors increase low density lipoprotein uptake and receptor number in cultured human liver cells. J Lipid Res 1991; 32:1889-97.

25. Stopeck AT, Nicholson AC, Mancini FP, Hajjar DP. Cytokine regulation of low density lipoprotein receptor gene transcription in HepG2 cells. J Biol Chem 1993; 268:17489-94.

26. Moorby CD, Gherardi E, Dovey DE, Godliman C, Bowyer $D E$. Transforming growth factor and Interleukin-1 $\beta$ stimulates LDL receptor activity in HepG2 cells. Atherosclerosis 1992; 97: 21-8.

27. Graham A, Russell LJ . Stimulation of low-density lipoprotein uptake in HepG 2 cells by epidermal growth factor via a tyrosine kinase-dependent, but protein kinase C-independent, mechanism. Biochem J 1994; 298:579-84.

28. Pak YK, Kanuck MP, Berrios D, Briggs MR, Cooper AD, Ellsworth J L. Activation of LDL receptor gene expression in HepG2 cells by hepatocyte growth factor. J Lipid Res 1996; 37:985-98.

29. Moran CS, Campbell J H, Campbell GR. Human leukemia inhibitory factor upregulates $\mathrm{LDL}$ receptors on liver cells and decreases serum cholesterol in the cholesterol-fed rabbit. Arterioscler Thromb Vasc Biol 1997; 17:1267-73.

30. Engelmann H, Novick D, Wallach D. Tumor necrosis factorbinding proteins purified from human urine. Evidence for immunological cross reactivity with cell surface tumor necrosis factor receptors. J Biol Chem 1990; 265:1531-6.

31. Van Zee KJ , Kohno T, Fischer E, Rock CS, Moldawer LL, Lowry SF. Tumor necrosis factor soluble receptors circulate during experimental and clinical inflammation and can protect against excessive tumor necrosis factor alpha in vitro and in vivo. Proc Natl Acad Sci 1992; 89:4845-9.

32. Memon RA, Grunfeld C, Moser AH, Feingold KR. Tumor necrosis factor mediates the effects of endotoxin on cholesterol and triglyceride metabolism in mice. Endocrinology 1993; 132:2246-53.

33. Feingold $K R$, Grunfeld $C$. Tumor necrosis factor-alpha stimulates hepatic lipogenesis in the rat in vivo. J Clin Invest 1987; 80:184-90.

34. Ettinger WH, Miller LD, Albers JJ, Smith TK, Parks J S. Lipopolysaccharide and tumor necrosis factor cause a fall in plasma concentration of lecithin: cholesterol acyltransferase in cynomolgus monkeys. J Lipid Res 1990; 31:1099-107.

35. Ettinger WH, Miller LA, Smith TK, Parks J S. Effect of interleukin-1 alpha on lipoprotein lipids in cynomolgus monkeys: comparison to tumor necrosis factors. Biochim Biophys Acta 1992; 1128:186-192.

36. Chajek-Shaul T, Friedman G, Stein O, Shiloni E, Etienne J , Stein Y. Mechanism of the hypertriglyceridemia induced by tumor necrosis factor administration to rats. Biochim Biophys Acta 1989; 1001:316-24.

37. Gouni I, Oka K, Etienne J , Chan L. Endotoxin-induced hypertriglyceridemia is mediated by suppression of lipoprotein lipase at a post-transcriptional level. J Lipid Res 1993; 34:139-46.

38. Feingold KR, Staprans I, Memon RA, Moser AH, Shigenaga J K, Doerrler W, et al. Endotoxin rapidly induces changes in 
lipid metabolism that produce hypertriglyceridemia: low doses stimulate hepatic triglyceride production while high doses inhibit clearance. J Lipid Res 1992; 33:1765-76.

39. Semb H, Peterson J , Tavernier J , Olivecrona T. Multiple effects of tumor necrosis factor on lipoprotein lipase in vivo. J Biol Chem 1987; 262:8390-4.

40. Lanza-J acoby S, Phetteplace H, Sedkova N, Knee G. Sequential alterations in tissue lipoprotein lipase, triglyceride secretion rates, and serum tumor necrosis factor alpha during Escherichia coli bacteremic sepsis in relation to the development of hypertriglyceridemia. Shock 1998; 9:46-51.

41. Feingold KR, Doerrler W, Dinarello CA, Fiers W, Grunfeld C. Stimulation of lipolysis in cultured fat cells by tumor necrosis factor, interleukin-1, and the interferons is blocked by inhibition of prostaglandin synthesis. Endocrinology 1992; 130:10-6.

42. Greenberg AS, Nordan RP, McIntosh J , Calvo J C, Scow RO, J ablons D. Interleukin 6 reduces lipoprotein lipase activity in adipose tissue of mice in vivo and in 3T3-L1 adipocytes: a possible role for interleukin 6 in cancer cachexia. Cancer Res 1992; 52:4113-6.

43. Doerrler W, Feingold KR, Grunfeld C. Cytokines induce catabolic effects in cultured adipocytes by multiple mechanisms. Cytokine 1994; 6:478-84.

44. Grunfeld C, Adi S, Soued M, Moser A, Fiers W, Feingold $K R$. Search for mediators of the lipogenic effects of tumor necrosis factor: potential role for interleukin 6. Cancer Res 1990; 50:4233-8.

45. Harris HW, Grunfeld C, Feingold KR, Rapp J H. Human very low density lipoproteins and chylomicrons can protect against endotoxin-induced death in mice. J Clin Invest 1990; 86:696-702.

46. Read TE, Grunfeld C, Kumwenda ZL, Calhoun MC, Kane J P, Feingold KR, et al. Triglyceride-rich lipoproteins prevent septic death in rats. J Exp Med 1995; 182:267-72.

47. Harris HW, Grunfeld C, Feingold KR, Read TE, Kane J P, J ones $\mathrm{AL}$, et al. Chylomicrons alter the fate of endotoxin, decreasing tumor necrosis factor release and preventing death. I Clin Invest 1993; 91:1028-34.

48. Read TE, Harris HW, Grunfeld C, Feingold KR, Calhoun MC, Kane J P, et al. Chylomicrons enhance endotoxin excretion in bile. Infect Immun 1993; 61:3496-502.

49. Rensen PC, Oosten M, Bilt E, Eck M, Kuiper J, Berkel TJ . Human recombinant apolipoprotein E redirects lipopolysaccharide from Kupffer cells to liver parenchymal cells in rats in vivo. J Clin Invest 1997; 99:2438-45.
50. Hubsch AP, Powell FS, Lerch PG. Doran-J E. A reconstituted, apolipoprotein A-I containing lipoprotein reduces tumor necrosis factor release and attenuates shock in endotoxemic rabbits. Circ Shock 1993; 40:14-23.

51. Feingold KR, Funk J L, Moser AH, Shigenaga J K, Rapp J H, Grunfeld C. Role for circulating lipoproteins in protection from endotoxin toxicity. Infect Immun 1995; 63:2041-6.

52. Weinstock C, Ullrich $H$, Hohe R, Berg A, Baumstark MW, Frey I, et al. Low density lipoproteins inhibit endotoxin activation of monocytes. Arterioscler Thromb 1992; 12:341-7.

53. Flegel WA, Baumstark MW, Weinstock C, Berg A, Northoff $H$. Prevention of endotoxin-induced monokine release by human low- and high-density lipoproteins and by apolipoprotein A-I. Infect Immun 1993; 61:5140-6.

54. Netea MG, De-Bont N, Demacker PN, Kullberg BJ , J acobs LE, Verver-J ansen TJ , et al. Lipoprotein(a) inhibits lipopolysaccharide-induced tumor necrosis factor alpha production by human mononuclear cells. Infect Immun 1998; 66:2365-7.

55. Wurfel MM, Hailman E, Wright SD. Soluble CD14 acts as a shuttle in the neutralization of lipopolysaccharide (LPS) by LPS-binding protein and reconstituted high density lipoprotein. J Exp Med 1995; 181:1743-54.

56. Pajkart D, Doran J E, Koster F, Lerch PG, Arnet B, van-derPoll T, et al. Antiinflammatory effects of reconstituted highdensity lipoprotein during human endotoxemia. J Exp Med 1996; 184:1601-8.

57. Kliewer SA, Sundseth SS, J ones SA, Brown PJ , Wisely GB, Koble CS, et al. Fatty acids and eicosanoids regulate gene expression through direct interactions with peroxisome proliferator-activated receptors alpha and gamma. Proc Natl Acad Sci USA 1997; 94:4318-23.

58. Staels B, Koenig W, Habib A, Merval R, Lebret M, Torra IP, et al. Activation of human aortic smooth-muscle cells is inhibited by PPARalpha but not by PPARgamma activators. Nature 1998; 393:790-3.

59. Rotondo D, Davidson J . Lipid metabolism [editorial]. Curr Opin Lipidol 1998; 9:503-5.

Received 26 November 1998; accepted 5J anuary 1999

Corresponding author: Dr. med. Peter Fraunberger, Institut für Klinische Chemie, Klinikum Grosshadern, Ludwig Maximilians Universität München, Marchioninistr. 15, D-81366 Munich, Germany

Tel.: +49-89-7095-3234, Fax: +49-89-7095-8888 